\title{
Factors Affecting Relative Growth Rate of Lettuce and Spinach in Hydroponics in a Greenhouse
}

\author{
Martin P.N. Gent ${ }^{1}$ \\ Forestry and Horticulture, Connecticut Agricultural Experiment Station, \\ New Haven, CT 06504-1106
}

Additional index words. electrical conductivity, irradiance, nitrate, $\mathrm{pH}$, temperature

\begin{abstract}
Relative growth rate (RGR), the relative increase in weight per day, can analyze the effect of environment and nutrition on growth. I examined which of the parameters responding to plant growth scaled according to RGR for lettuce and spinach grown in heated greenhouses in hydroponics with control of the nutrient solution. The experiments for lettuce in 2006-08 included all times of year, high vs. low temperature, and effect of withdrawal of nitrogen. There were four parameters that were significant in multiple linear regression vs. RGR; irradiance divided by leaf area index if it was greater than one, or normalized daily light integral (NDLI), solution temperature, electrical conductivity (EC), and logarithm solution nitrate when it was between 3 and $55 \mathrm{mg} \cdot \mathrm{L}^{-1} \mathrm{~N}$. NDLI had the most significant coefficient, but the other parameters had regression coefficients more than three times SE. For experiments on spinach in 2009-10, all the parameters mentioned previously were significant in multiple linear regression vs. RGR, except EC. The coefficient for NDLI in spinach was about half the value in lettuce. The coefficients for solution temperature and low nitrate were two and three times that in lettuce. In a third set of experiments on lettuce in 1996-98, solution temperature was the only significant parameter among those mentioned previously. The coefficient for solution temperature was similar to that for regression of lettuce in 2006-08.
\end{abstract}

Several studies have shown environment and nutrition have effects on growth of lettuce. RGR, the relative increase in weight per day, changes slowly as plants grow in a constant environment. What are the components of plant growth that scale according to RGR? To what extent are these determined by irradiance or time of year and by conditions of the nutrient solution in hydroponics?

Irradiance is the primary factor affecting RGR (Gent, 2014). However, a function of light intercepted by the crop may be better related to RGR. Bierhuizen et al. (1973) showed that shoot dry weight of lettuce was linearly related to radiation corrected for soil cover and leaf area growth was related to degree days. Additive Gomperz functions in soil temperature and radiation correlated with head weight better than either factor alone (Salomez and Hofman, 2007). The rate of photosynthesis of lettuce increased with light intensity (Park and Yong Beom, 2001). When leaf area index was less than one, there was a linear relation between $\mathrm{CO}_{2}$ consumption and leaf area of lettuce crops in a plant factory (Choi et al., 2014). How would such a function be changed to predict RGR for leaf area index greater than one?

Temperature may affect plant growth. The most rapid growth of lettuce in a controlled environment was at $25 / 25^{\circ} \mathrm{C}$ day/

Received for publication 7 Aug. 2017. Accepted for publication 6 Nov. 2017.

${ }^{1}$ Corresponding author. E-mail: martin.gent@ct. gov. night temperature (Knight and Mitchell, 1983). The maximum dry weight of lettuce in a greenhouse was at $24 / 24{ }^{\circ} \mathrm{C}$ air/root temperature (Thompson et al., 1998), and a $17{ }^{\circ} \mathrm{C}$ air or root temperature resulted in less growth. When temperature was varied during the day, it did not affect growth, except when the minimum temperature was at dawn (Miller and Langhans, 1985). There was no interaction of effects of day and night, or air and root temperatures in hydroponics (Hicklenton and Wolynetz, 1987), but the leaf area-to-dry weight ratio increased with both day and night temperatures to $23 / 19{ }^{\circ} \mathrm{C}$ day/night. Under tropical conditions, the longer the period with temperature controlled at $20^{\circ} \mathrm{C}$, the higher the biomass (Qin et al., 2002). There was no effect of day to night temperature differences on lettuce growth when it changed because of light intensity (Eguchi et al., 1997).

The $\mathrm{pH}$ or concentration of various elements could affect growth in hydroponics. The concentration of elements is related to EC. A solution EC of 1.2 to $4.8 \mathrm{dS} \cdot \mathrm{m}^{-1}$ did not affect photosynthesis of lettuce (Park and Yong Beom, 2001). Yield decreased when EC increased from 2.8 to 3.8 or $4.8 \mathrm{dS} \cdot \mathrm{m}^{-1}$ (Scuderi et al., 2009). However, lettuce had faster growth in summer than in winter when nitrate was raised from 2.5 to $10 \mathrm{~mm}$ (Van der Boon et al., 1990). Of the limiting nutrients for lettuce, the relation of nitrate to growth is most complex. Lettuce grown in sand was $\mathrm{N}$ deficient at $2 \mathrm{~mm}$ nitrate, $28 \mathrm{mg} \cdot \mathrm{L}^{-1}$ nitrogen, and suffered salt toxicity at $36 \mathrm{~mm}$ nitrate, $504 \mathrm{mg} \cdot \mathrm{L}^{-1} \mathrm{~N}$ (Huett and White, 1992). In hydroponics, there was a linear relation between RGR and tissue $\mathrm{P}$ or $\mathrm{K}$, but there was rapid growth until tissue nitrate was depleted (Burns, 1992). This may be due to the relation with organic $\mathrm{N}$ in tissue (Burns, 1994). Hydroponic lettuce switched to a nonitrate solution at various times had changes in growth such that there was no growth at $1 \%$ organic $\mathrm{N}$ by dry weight, up to control growth at greater than $4 \% \mathrm{~N}$ (Broadley et al., 2003). The change in nitrate concentration in plant tissue with irradiance was much greater than the effect on total nitrogen (Demsar et al., 2004). This resulted in an interaction of effects of nitrate and irradiance on growth (De Pinheiro Henricques and Marcelis, 2000). There was a linear relation between the maximum rate of nitrate inflow into lettuce roots and RGR, as affected by radiation, temperature, or plant size, but there was little relation with the nitrate concentration in the plant (Steingrobe and Schenk, 1994).

There are fewer reports on the effect of environment on growth of spinach. The effects of solution nitrate on spinach growth were similar to those for lettuce. Nitrate withdrawal for $2 \mathrm{~d}$ did not affect fresh weight, but tissue nitrate dropped from 3000 to $600 \mathrm{ppm}$ at $4 \mathrm{~d}$ (Fukuda et al., 1999). Spinach growth decreased at $4 \mathrm{~d}$ with nitrate withdrawal under high light and at $2 \mathrm{~d}$ when switched from high to low light (Buysse et al., 1996). RGR of spinach was proportional to the reduced $\mathrm{N}$ in leaf tissue minus the minimum concentration required for growth (Smolders and Merckx, 1992). Solution concentrations of 0.8 or $4 \mathrm{~mm}$ nitrate gave an RGR of 0.17 and 0.25 for spinach (Ter Steege et al., 1998). The nitrate concentration in solution affected nitrate in leaves. It was 2 -fold higher at 4.0 compared with $0.8 \mathrm{~mm}$ nitrate in solution (Ter Steege et al., 1998). When spinach was grown in solutions with different nutrient proportions, the solution with highest nitrate and $\mathrm{K}$ and total nutrients gave the highest fresh weight (Rivera et al., 2009).

Previously, I studied the effects of environment on composition of metabolites in lettuce and spinach (Gent, 2014, 2016). In lettuce, much of the variation in tissue composition on a fresh weight basis was related to NDLI (Gent, 2014). Except for nitrate, metabolite concentrations on a fresh weight basis increased with irradiance, and the changes in sugars due to irradiance were greater when plants were harvested in the afternoon rather than in the morning. The NDLI also explained much of the variation in composition of spinach (Gent, 2016). However, unlike in lettuce, sugars in spinach decreased more with an increase in temperature than expected from NDLI. This was related to a decrease of sugars in spinach petioles with temperature up to $20^{\circ} \mathrm{C}$. From 1996 to 1998 , I changed the ratio of nitrate to other nutrients to see if this affected the growth of lettuce (Gent, 2003). In those experiments, lettuce required more nitrate for growth in summer than in winter. Is the 
RGR for lettuce and spinach predicted by the same environmental variables for all these experiments?

\section{Materials and Methods}

Growth conditions. The experiments were conducted in greenhouses in Hamden, CT, USA (lat. $42^{\circ} \mathrm{N}$, long. $73^{\circ} \mathrm{W}, 50 \mathrm{~m}$ above sea level). These were single-span hoop houses, $17.1-\mathrm{m}$ long $\times 4.3-\mathrm{m}$ wide $\times 2.7-\mathrm{m}$ high, with a double glazing of $0.1-\mathrm{mm}$ clear polyethylene film. Heating and ventilating set points were 17 and $22{ }^{\circ} \mathrm{C}$. Horizontal air fans circulated air through the greenhouses. From mid-June to September in 2006-10, the sides were rolled up to a height of $1.5 \mathrm{~m}$ to improve ventilation and $30 \%$ shadecloth was applied. Shaded thin-wire thermocouples and temperature humidity transmitters (model 500; Campbell Scientific, Logan, UT) measured air temperature at a height of $1.5 \mathrm{~m}$ in the center of each greenhouse. Quantum sensors (model 190; LI-COR, Lincoln, NE) measured photosynthetic active radiation within the greenhouse above the height of the crop. Another sensor measured ambient sunlight in an unobstructed location. Readings from each sensor were taken every minute, averaged hourly, and recorded.

Two hydroponic systems, each of which could support 12 troughs or rows of plants, were constructed in each of two greenhouses. These systems were run simultaneously by a single data-logging computer (Model CR10; Campbell Scientific). Troughs for the two systems were alternated along the length of the house. The troughs were supported by a wooden frame to give a $1.5 \%$ slope from inlet to outlet. In 2006-10, the troughs were $3-\mathrm{m}$ long and $4 \times 10 \mathrm{~cm}$ in cross-section, with $20 \mathrm{~cm}$ between plants in each trough and between troughs (model CHA 9004/9010; Crop King, Lodi, OH). Each system had a nutrient reservoir: a $200-\mathrm{L}$ removable-top polyethylene drum (model H-06 950-35; Cole Parmer Inst. Co., Vernon Hills, IL) insulated and buried in the ground and covered with black polyethylene film to exclude light. Solution from the nutrient reservoir was passed through a cotton-string core filter. A magnetic drive pump (model SM1212-26; Liang, Chula Vista, CA) supplied the high end of each trough at $1 \mathrm{~L} \cdot \mathrm{min}^{-1}$. Solution flowed by gravity to the low end of each trough and into a manifold that returned solution to the nutrient reservoir for each system. The hydroponic systems circulated water for $3 \mathrm{~min}$ in a $-5,10-$, or 20-min cycle, depending on sunlight intensity.

Nutrients. Water and nutrient concentrates were injected automatically to maintain a constant system volume and EC. A float switch (model M800B; Madison Controls, Branford, CT) was mounted inside the reservoir to maintain $100 \mathrm{~L}$ of solution within the reservoir. Whenever the float switch was below the set point, a solenoid valve (model SV4212DB24; Valcor Engineering, Springfield, NJ) injected water at $0.12 \mathrm{~L} \cdot \mathrm{min}^{-1}$ through a flow restriction consisting of a $10-\mathrm{cm}$ length of $0.75-\mathrm{mm}$ i.d. $\times 1.6-\mathrm{mm}$ o.d. polyetheretherketone tubing (model 1533; Upchurch Scientific, Oak Harbor, WA). An electrode to measure EC and temperature (model 35 820-62; ThermoFisher Scientific, Pittsburgh, PA) was mounted inline in the supply manifold. When EC was less than 1.2 $\mathrm{dS} \cdot \mathrm{m}^{-1}$, peristaltic pumps (model FPU104; Omega Engineering, Stamford, CT) injected two nutrient concentrate solutions at 3 $\mathrm{mL} \cdot \mathrm{min}^{-1}$. One was a complete fertilizer, 4 14-34 N- $\mathrm{P}_{2} \mathrm{O}_{5}-\mathrm{K}_{2} \mathrm{O}$ (Hydro Gro; CropKing, Lodi, $\mathrm{OH})$ at $25 \mathrm{~g} \cdot \mathrm{L}^{-1}$, with concentrated phosphoric acid $1.25 \mathrm{~mL} \cdot \mathrm{L}^{-1}$, iron chelate at $0.2 \mathrm{~g} \cdot \mathrm{L}^{-1}$, and $\mathrm{MnSO}_{4} \cdot 2 \mathrm{H}_{2} \mathrm{O}$ at $0.1 \mathrm{~g} \cdot \mathrm{L}^{-1}$. The other was greenhouse-grade calcium nitrate at $20 \mathrm{~g} \cdot \mathrm{L}^{-1}$. The nutrient solutions were sampled each time plants were harvested and analyzed for $\mathrm{pH}$ and $\mathrm{EC}$, and by nitrate and potassium electrodes and inductively coupled plasma spectrometry (Gent, 2014). The dilute solution had adequate concentrations of all essential elements, as shown in Table 1.

Plant material. Seeds of butter head lettuce (Lactuca sativa L.) 'Buttercrunch' and spinach (Spinacea oleracea L.) 'Tyee' were from Johnny's Seeds (Winslow, ME). Seeds were germinated under controlled conditions, 16-h photoperiod at $100 \mu \mathrm{E} \cdot \mathrm{m}^{-2} \cdot \mathrm{s}^{-1}$ and $25{ }^{\circ} \mathrm{C}$, in an artificial medium (model LC1 Horticubes; Smithers Oasis, Kent, $\mathrm{OH}$ ). Two weeks after germination, the seedlings were transplanted to the greenhouse hydroponic systems.

Lettuce plants were harvested 2-6 weeks after transplanting. Among the plantings harvested in the interval from July 2006 to Nov. 2008, a total of 16 were selected, including those that varied in temperature or solution composition. Plants were harvested from one greenhouse in 2006, and two greenhouses in 2007 and 2008. For nine plantings, there were two harvests, at $\approx 1500$ $\mathrm{HR}$ and at 0600 to $0900 \mathrm{HR}$ the following day. For seven plantings, there was only one harvest, at 1200 to $1300 \mathrm{HR}$. Five plantings of spinach were harvested in the interval from June to Nov. 2009. Plants were harvested 3-4 weeks after transplanting in summer and 5-8 weeks after transplanting in fall. Harvests were at 1400 to $1500 \mathrm{HR}$ and at 0700 to 0800 HR the following day. A final planting was harvested on 25 June 2010 to study the effect of nitrogen depletion and resupply. The first three harvests in 2009 were from a single greenhouse. The other two harvests in 2009 and the diurnal harvest in 2010 were from two greenhouses.

Harvests. At each harvest, four plants were randomly selected from each system, each from a different trough and position along the trough. Whole plant fresh weights were recorded. Roots were cut off the Oasis cube, washed in tap water, dried by centrifugal force, and weighed. The shoot of each plant was divided into halves or quarters. A set of subsamples was used to the determine biomass. The midrib (petiole) was dissected from the leaf blade. These parts were weighed separately, and the leaf blade area was determined. This harvest and measurement operation took 5-10 $\mathrm{min}$ for one replication of each planting. The biomass samples were dried at $75^{\circ} \mathrm{C}$ and reweighed. The RGR was determined from the shoot weights harvested at 4- to 9-d intervals, depending on the time of year, using the equation

Relative growth rate

$=\left\{\ln \left(\right.\right.$ weight $\left._{2}\right)-\ln \left(\right.$ weight $\left.\left._{1}\right)\right\} /\left(\right.$ day $_{2}-$ day $\left._{1}\right)$.

Another experiment measured the lettuce grown in similar troughs in 1996-98. The experimental conditions are described elsewhere (Gent, 2003).

Regressions. Values of irradiance, temperature, and EC were recorded hourly and compiled into mean values for $5 \mathrm{~d}$ before harvest. The natural logarithm of irradiance was used as this fit the data for lettuce in 199698. The NDLI was calculated from mean irradiance divided by leaf area index (LAI) at

Table 1. Concentrations of elements injected into the nutrient solution and found by analysis in the years 2006-08.

\begin{tabular}{lrrrrrrrrrr}
\hline & Nitrate $\mathrm{N}$ & $\mathrm{K}$ & $\mathrm{P}$ & $\mathrm{Ca}$ & $\mathrm{Mg}$ & $\mathrm{Fe}$ & $\mathrm{Mn}$ & $\mathrm{Zn}$ & $\mathrm{Cu}$ & $\mathrm{Na}$ \\
\cline { 2 - 10 } Factor & \multicolumn{7}{c}{} & \multicolumn{7}{c}{$\left(\mathrm{mg} \cdot \mathrm{L}^{-1}\right)$} & & & \\
\hline Injected & 142 & 278 & 98 & 120 & 28 & 5.5 & 1.0 & 0.5 & 0.13 \\
Found & 94 & 157 & 44 & 148 & 46 & 0.63 & 0.13 & 0.16 & 0.76 & 20 \\
SD & 20 & 39 & 20 & 35 & 15 & 0.20 & 0.08 & 0.05 & 0.19 & 4 \\
\hline
\end{tabular}

Table 2. Statistics for variables related to relative growth rate of lettuce in 2006-08.

\begin{tabular}{lcccccc}
\hline Factor & Mean & Minimum & Maximum & SD & Covariance & Correlation with RGR \\
\hline Relative growth rate & 0.113 & -0.036 & 0.295 & 0.064 & 0.57 & -0.18 \\
Leaf area index & 3.14 & 0.066 & 10.29 & 2.2 & 0.701 & 0.25 \\
pH & 6.91 & 6.00 & 7.52 & 0.366 & 0.053 & 0.25 \\
Electrical conductivity & 1.33 & 0.57 & 2.09 & 0.26 & 0.195 & 0.53 \\
Air temperature & 19 & 10.8 & 29.7 & 4.31 & 0.227 & 0.54 \\
Solution temperature & 18.4 & 11.0 & 29.0 & 4.17 & 0.227 & 0.42 \\
Logarithm irradiance & 2.24 & 1.34 & 3.19 & 0.593 & 0.265 & 0.55 \\
NDLI & 4.94 & 0.67 & 17.35 & 4.01 & 0.812 & 0.034 \\
Logarithm $\left(\mathrm{NO}_{3}\right)^{\mathrm{z}}$ & 0.87 & 0.25 & 1.00 & 0.27 & 0.311 & \\
\hline
\end{tabular}

$\mathrm{RGR}=$ relative growth rate; NDLI $=$ normalized daily light integral.

${ }^{\mathrm{z}} 0.25 * \operatorname{logarithm}\left(\mathrm{NO}_{3}\right)$ if less than $55 \mathrm{mg} \cdot \mathrm{L}^{-1}$, otherwise 1.0 . 
Table 3. Coefficients and SEs for the regression parameters correlated with relative growth rate of lettuce in 2006-08.

\begin{tabular}{lrc}
\hline Term & Coefficient & \multicolumn{1}{c}{ SE } \\
\hline Constant & -0.1158 & \pm 0.0287 \\
NDLI & 0.0081 & \pm 0.0010 \\
Solution temperature & 0.0058 & \pm 0.0010 \\
Electrical conductivity & 0.0420 & \pm 0.0163 \\
Logarithm $\left(\mathrm{NO}_{3}\right)^{\mathrm{z}}$ & 0.0340 & \pm 0.0149 \\
\hline
\end{tabular}

NDLI $=$ normalized daily light integral.

${ }^{\mathrm{z}} 0.25 *$ logarithm $\left(\mathrm{NO}_{3}\right)$ if less than $55 \mathrm{mg} \cdot \mathrm{L}^{-1}$, otherwise 1.0 . harvest. NDLI was the mean irradiance if LAI and was less than 1 . Values for $\mathrm{pH}$ and nitrate came from analysis of nutrient solutions. Nitrate nitrogen only affected growth when it was less than $55 \mathrm{mg} \cdot \mathrm{L}^{-1} \mathrm{~N}\left(4 \mathrm{mmol} \cdot \mathrm{L}^{-1}\right)$. The value of solution nitrate concentration used in regression was $0.25 *$ logarithm nitrate if it was between 3 and $55 \mathrm{mg} \cdot \mathrm{L}^{-1} \mathrm{~N}$. Values were 0.25 at less than $3 \mathrm{mg} \cdot \mathrm{L}^{-1}$ and 1.0 at greater than $55 \mathrm{mg} \cdot \mathrm{L}^{-1}$. Regressions were done in SYSTAT (Version 10.2; Systat Software, Inc., San Jose, CA). Multiple linear regression

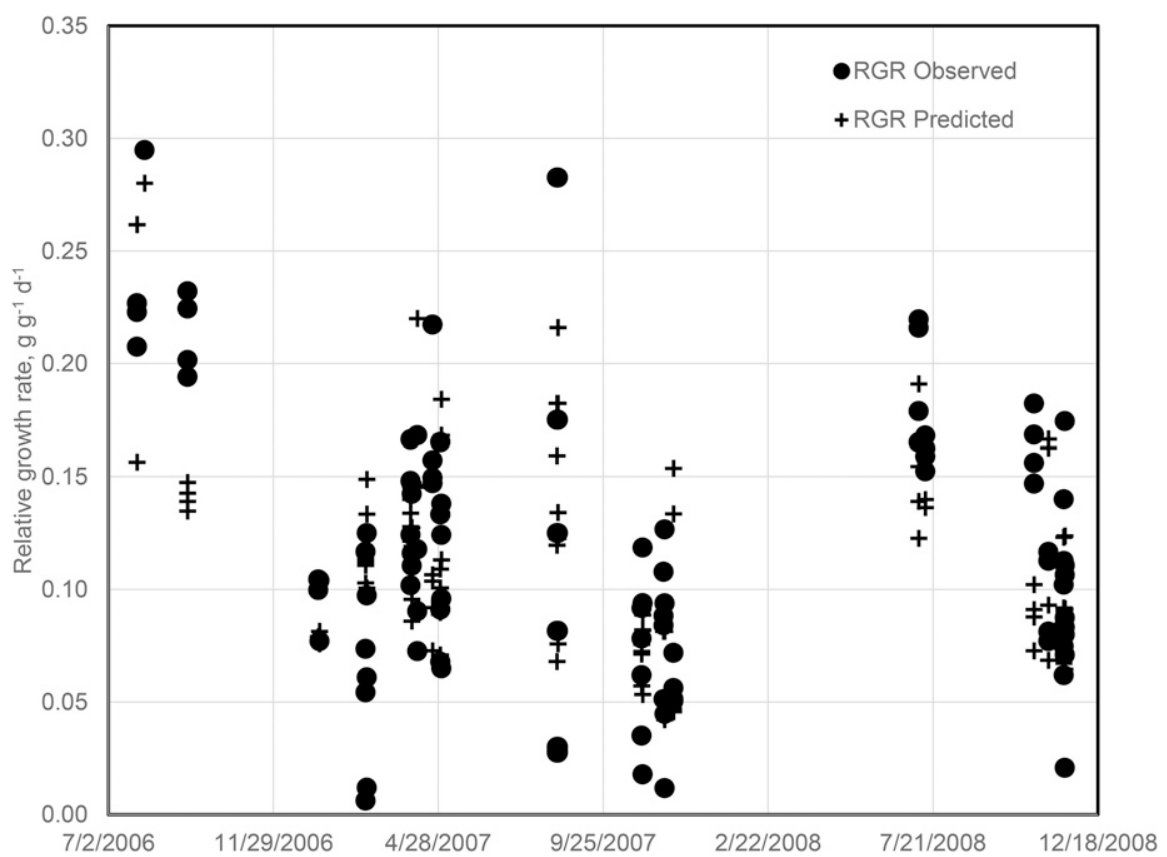

Fig. 1. Observed relative growth rates of lettuce in 2006-08 and values predicted from regression vs. four significant variables.

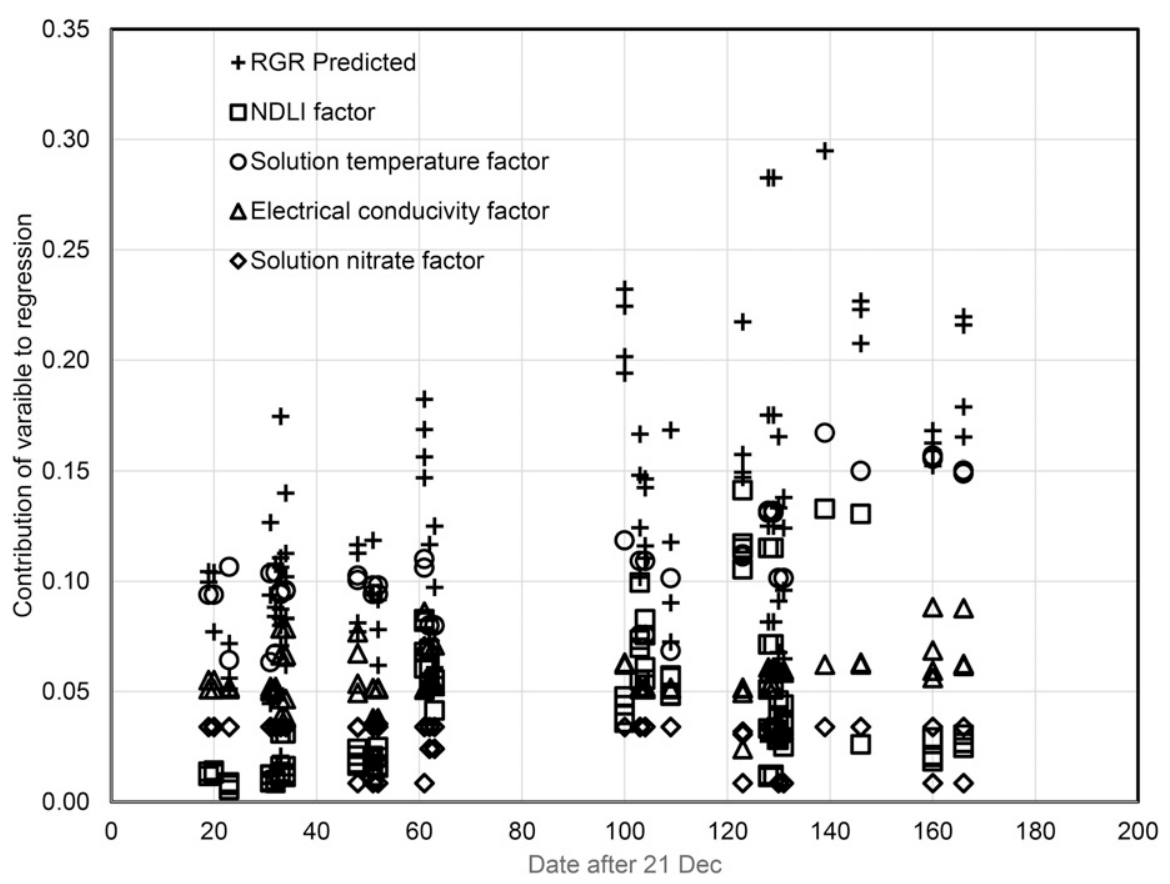

Fig. 2. Predicted relative growth rate of lettuce in 2006-08 and the contributions of four significant variables to the regression; normalized daylight integral (NDLI), solution temperature, electrical conductivity, and solution nitrate. was used to find the parameters significantly correlated with RGR, with the condition that the $F$ statistic to enter was $F>4.0$.

\section{Results}

Lettuce 2006-08. During these 3 years, 110 values were obtained, including replications, in which the RGR of lettuce was compared with environmental and solution parameters. The mean RGR for all experiments in 2006-08 was 0.11 , with a minimum of $0.00(-0.04)$, a maximum of 0.30 , and a CV of 0.57 (Table 2). Temperature of the air and the solution, and irradiance were the environment factors that affected RGR. Leaf area index and NDLI were two parameters that were related to the size of the plants. As shown in studies of the effect of irradiance on composition of lettuce and spinach, NDLI accounted for a large part of the effect of size on plant growth (Gent, 2014,2016). Over all experiments in 2006-08, NDLI had the largest $\mathrm{CV}$ varying from 2 to $18 \mathrm{MJ} \cdot \mathrm{m}^{-2} \cdot \mathrm{d}^{-1}$. The experiments included different minimum temperatures of 10 compared with $20{ }^{\circ} \mathrm{C}$, harvested on 1 Apr. 2007 and 30 Nov. 2007. Otherwise, average temperatures varied from $14{ }^{\circ} \mathrm{C}$ in winter to $27^{\circ} \mathrm{C}$ in summer.

The RGR was also affected by $\mathrm{pH}, \mathrm{EC}$, and solution nitrate. However, there was little variation observed in $\mathrm{pH}$. Several experiments provided different solution nitrate concentrations; harvested around 1 May 2007, 14 Nov. 2007, and 1 Oct. 2008. For these experiments, we measured RGR $5 \mathrm{~d}$ after solution nitrate had been changed, so the effect of solution nitrate on plant growth had taken place.

The correlation between RGR and these variables varied from -0.18 for leaf area index to 0.55 for NDLI (Table 2). The highest covariation among the variables used to predict RGR was between solution and air temperature. Multiple linear regression was used to find those variables that were highly correlated with RGR for lettuce. When all the variables were added in the regression, the regression coefficient was $R^{2}=0.65$ and the constant was negative, -0.47 . Most variables made a positive contribution to regression. Air temperature and logarithm irradiance were the only variables not well correlated with RGR. Stepwise linear regression with an $F$-to-enter $>4$ was used to find those variables most significantly related to RGR. This resulted in a model with four significant variables and $R^{2}=0.53$. The variables were NDLI, solution temperature, EC, and solution nitrate. The NDLI and solution temperature had the highest correlations, $P<0.0001$. This regression was improved by deleting three outliers, resulting in $R^{2}=0.57$. Of the variables in regression, NDLI had the highest $\mathrm{CV}, 0.0081$ (Table 3). Solution temperature had a nearly equal significance, but a smaller $\mathrm{CV}$ over all data. The EC and solution nitrate had smaller coefficients of variation, but their significances was $P<0.05$. The constant was negative, -0.12 , and all regression coefficients were positive (Table 3 ). 
Table 4. Statistics for variables related to relative growth rate of spinach in 2009-10.

\begin{tabular}{|c|c|c|c|c|c|c|}
\hline Factor & Mean & Minimum & Maximum & SD & Covariance & Correlation with RGR \\
\hline Relative growth rate & 0.134 & 0.051 & 0.240 & 0.061 & 0.456 & \\
\hline Leaf area index & 1.51 & 0.64 & 3.2 & 0.6 & 0.398 & -0.10 \\
\hline $\mathrm{pH}$ & 6.15 & 5.54 & 6.99 & 0.313 & 0.051 & -0.34 \\
\hline Electrical conductivity & 2.63 & 1.09 & 3.37 & 0.858 & 0.327 & 0.53 \\
\hline Air temperature & 20.2 & 16.1 & 23.5 & 2.54 & 0.126 & 0.59 \\
\hline Solution temperature & 20.9 & 16.3 & 24.3 & 2.75 & 0.132 & 0.61 \\
\hline Logarithm irradiance & 1.12 & 1.0 & 1.38 & 0.09 & 0.08 & -0.01 \\
\hline NDLI & 13.7 & 3.7 & 27.1 & 7.381 & 0.54 & 0.40 \\
\hline Logarithm $\left(\mathrm{NO}_{3}\right)^{\mathrm{z}}$ & 0.89 & 0.26 & 1.00 & 0.247 & 0.279 & 0.09 \\
\hline
\end{tabular}

$\mathrm{RGR}=$ relative growth rate; NDLI $=$ normalized daily light integral.

${ }^{\mathrm{z}} 0.25 * \operatorname{logarithm}\left(\mathrm{NO}_{3}\right)$ if less than $55 \mathrm{mg} \cdot \mathrm{L}^{-1}$, otherwise 1.0 .

The actual RGRs were compared with the values expected from regression, and these were plotted vs. date (Fig. 1). The highest RGRs were in summer, and the lowest were in November to February. The predicted RGRs were plotted vs. Julian date after 21 Dec., the date of minimum irradiance, and compared with the regression coefficients for the four variables mentioned previously (Fig. 2). The NDLI made the largest contribution to regression, varying from 0.02 to 0.14 . Solution temperature had a nearly equal contribution, varying from 0.06 to 0.17 primarily affected by time of year. The contribution of EC varied from 0.04 to 0.08 . The coefficient for solution nitrate was 0.03 , except it was 0.01 in those experiments where the nitrate supply was curtailed.

Spinach 2009-10. There were 30 values obtained for spinach, including replications, where RGR was compared with solution and environmental variables. Over all values in 2009-10, the mean RGR was 0.13, with a minimum of 0.05 , a maximum of 0.24 , and a $\mathrm{CV}$ of 0.46 (Table 4). Among the environment factors that affected RGR, solution temperature had the greatest correlation, 0.61. The parameters related to the nutrient solution had the smallest coefficients of variation, 0.05 and 0.08 , for $\mathrm{pH}$ and $\mathrm{EC}$, respectively. There was one set of data with different solution nitrate concentrations, harvested in June 2010.

Multiple linear regression was used to find those variables that were most highly correlated with RGR, as for lettuce. When all the variables were added in the regression, $R^{2}=$ 0.58 , with a negative constant of -0.05 . The variables that were significantly correlated with RGR were air temperature, solution temperature, and NDLI. Only air temperature had a positive coefficient. Stepwise linear regression with an $F$-to-enter $>4$ was used to find those variables most significantly correlated with RGR. This resulted in a model with three significant variables and $R^{2}=0.39$. The variables were NDLI, solution temperature, and concentration of nitrate in the nutrient solution. Solution temperature had the highest significance, $P<0.004$. This regression was improved by deleting three outliers, giving $R^{2}=0.76$ and a constant of -0.26 (Table 5). Of the variables in this regression, NDLI had the highest significance, $P<$ 0.0001 . Solution temperature had a lower significance, $P<0.002$, but a larger $\mathrm{CV}$ over all data. Solution nitrate had slightly less significance, $P<0.003$. All coefficients were positive.

Actual RGRs were compared with the values expected from regression and plotted vs. date (Fig. 3). The RGRs were highest in summer and lowest in October and November. Furthermore, predicted RGRs were plotted vs. Julian date after 21 Dec. and compared with the regression coefficients for the three variables mentioned previously (Fig. 4). The effect of NDLI, varied from 0.03 to 0.10 . This was only half the value in the lettuce model. Solution temperature had a greater contribution in spinach than in lettuce, varying from 0.22 to 0.32 . The coefficient for solution nitrate dropped from 0.09 to as low as 0.02 in one experiment where the nitrate supply was curtailed.

Lettuce 1996-98. In these years, 56 values for lettuce RGR, including replications, were obtained to compare with environment and solution parameters. The protocol given by Gent (2003) was different from the protocols used in the experiments on lettuce and spinach described previously, in that solution nitrate was varied in each experiment. The mean RGR over all values was 0.13 , with a minimum of 0.06 , a maximum of 0.19 , and a $\mathrm{CV}$ of 0.26 . Of the plant size and environment factors that affected RGR, NDLI had the greatest $\mathrm{CV}, 0.53$, and leaf area index was next, 0.42 (data not shown). Temperature had an effect only due to time of year. Of the parameters related to the nutrient solution, $\mathrm{pH}$ had the smallest $\mathrm{cv}, 0.11$.

Multiple linear regression was used to find those variables that were most highly correlated with RGR. When all the variables were added in regression, the $R^{2}=0.55$. In this regression, the constant was negative, -0.05 , as were the coefficients for LAI and NDLI. All other coefficients were positive. The variables that were most highly correlated with RGR were $\mathrm{pH}$ and logarithm irradiance. Using the parameters most significant for lettuce in 2006-08 gave a model with solution temperature as the only significant variable, with a coefficient of $0.0048, P<0.002$, and $R^{2}=0.37$

To gain insight into the factors that affected regression, the predicted RGRs in 1996-98 were plotted vs. Julian date after 21 Dec. and compared with the expected values from several variables. Solution temperature, the only significant variable, was most
Table 5. Coefficients and SES for the regression parameters correlated with relative growth rate of spinach in 2009-10.

\begin{tabular}{lcc}
\hline Term & Coefficient & SE \\
\hline Constant & -0.2634 & \pm 0.0599 \\
NDLI & 0.0043 & \pm 0.0012 \\
Solution temperature & 0.0131 & \pm 0.0027 \\
Logarithm $\left(\mathrm{NO}_{3}\right)^{\mathrm{z}}$ & 0.0885 & \pm 0.0257 \\
\hline
\end{tabular}

NDLI = normalized daily light integral.

${ }^{\mathrm{z}} 0.25 *$ logarithm $\left(\mathrm{NO}_{3}\right)$ if less than $55 \mathrm{mg} \cdot \mathrm{L}^{-1}$ otherwise 1.0.

affected in Winter and Spring 1998 (data not shown). The $\mathrm{pH}$ and logarithm irradiance were two other variables that affected RGR in 1996-98. The lowest was $\mathrm{pH}=4$, in July 1996 and Apr. 1998, and this had a negative effect on growth. The low $\mathrm{pH}$ was due to addition of nitric acid, which was used as a source of nitrate in these experiments, at a time when there was a lack of large plants to titrate the $\mathrm{pH}$ in the hydroponic system. Logarithm irradiance had a contribution that varied from 0.04 in Winter to 0.09 in Spring 1998. It was $0.08-0.11$ in all other experiments in 1996-98.

\section{Discussion}

Lettuce 2006-08. For these experiments on lettuce, NDLI had the highest $\mathrm{CV}$ with RGR, followed by solution temperature. The $\mathrm{EC}$ and solution nitrate had smaller coefficients of variation. Bierhuizen et al. (1973) showed that dry weight was linearly related to radiation corrected for soil cover, which is closely related to NDLI in the present study. Other studies have shown that $\mathrm{CO}_{2}$ consumption increased linearly with leaf area when it was less than one (Choi et al., 2014). In our study, solution and air temperature were highly correlated, but there was a greater effect of solution temperature on RGR. There were no second-order effects of temperature. At least up to $27{ }^{\circ} \mathrm{C}$, I found only a linear effect of temperature on RGR. Scaife (1973) demonstrated that during early growth of lettuce RGR increased linearly with temperature to $23{ }^{\circ} \mathrm{C}$.

Over these experiments, EC varied from 0.7 to $2.3 \mathrm{dS} \cdot \mathrm{m}^{-2}$ and RGR increased with EC. Manganese was one element that was depleted in the nutrient solution in 2006 . The plantings in 2006 did not have the iron and manganese that was added in later 


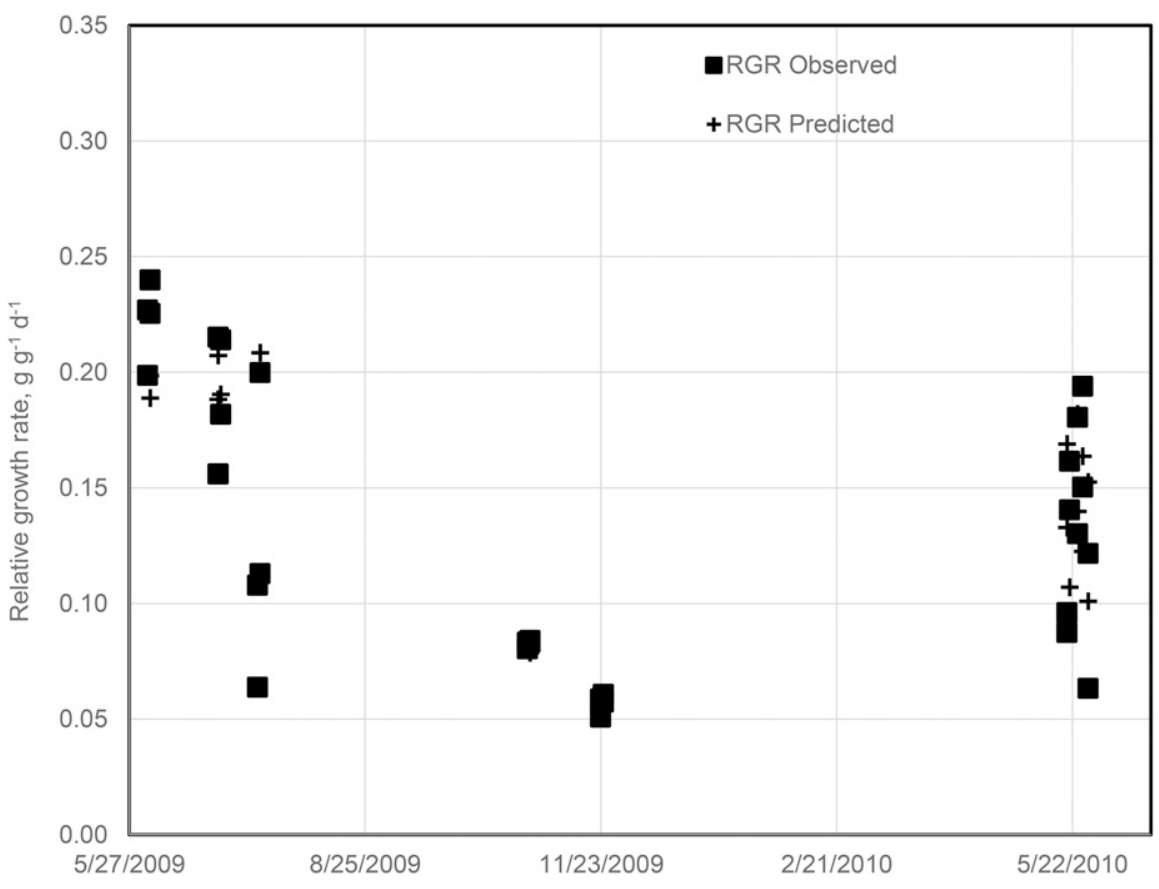

Fig. 3. Observed relative growth rates of spinach in 2009-10 and values predicted from regression vs. three significant variables.

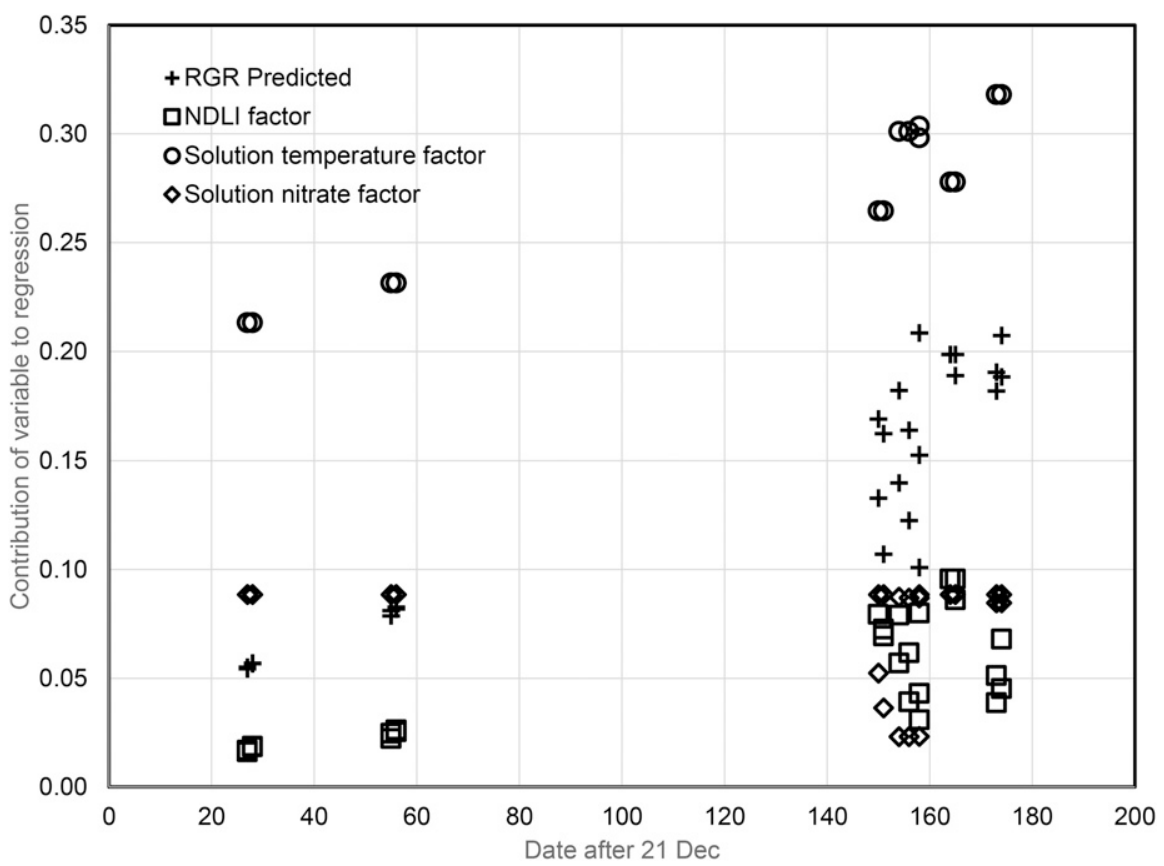

Fig. 4. Predicted relative growth rate of spinach in 2009-10 and the contributions of three significant variables to the regression; normalized daylight integral (NDLI), solution temperature, and solution nitrate.

plantings. Photosynthesis was unaffected when lettuce plants were grown at an EC of 1.2 to $4.8 \mathrm{mS} \cdot \mathrm{cm}^{-1}$; however, photosynthesis did increase with light intensity (Park and Yong Beom, 2001). Yield decreased when EC increased from 2.8 to 3.8 or $4.8 \mathrm{dS} \cdot \mathrm{m}^{-1}$ (Scuderi et al., 2009). Other studies have shown that the effect of nitrate in lettuce is correlated with protein and/or organic nitrogen (Broadley et al., 2003; Burns, 1994), rather than tissue nitrate (Gent, 2014). spinach experiments. When spinach was grown in solutions with different nutrient proportions, the solution with highest nitrate, potassium, and total nutrients gave the highest fresh weight (Rivera et al., 2009). When grown in high tunnels, the RGR of spinach was reduced more than that of lettuce by low light or temperature (Gent, 2002). The regression coefficient for the effect of solution nitrate on growth was greater for spinach than for lettuce, 0.09 and 0.03 , respectively. There was only one experiment with spinach that lowered solution nitrate, compared with three for lettuce. Part of the effect of solution nitrate on lettuce growth in 2006-08 may have been explained by the effect of EC instead.

Lettuce 1996-98. The $\mathrm{pH}$ and logarithm irradiance were the variables most significantly correlated with RGR for lettuce in 1996-98. The $\mathrm{pH}$ varied from 4.1 to 8.1 and logarithm irradiance varied from 0.9 to 2.4 . When lettuce was grown at various $\mathrm{pHs}$ from 5 to 8 (Roosta, 2011), the fastest growth and photosynthesis was at $\mathrm{pH} 5$. In my study, a $\mathrm{pH}$ of 4 had a negative effect on growth. In the 1996-98 experiments, the logarithm of irradiance was more related to RGR than was NDLI, because leaf area indices were similar across experiments. The NDLI only varied from 0.5 to 3.3. The variables that were most significant for lettuce in 2006-08 gave negative regression coefficients when used in regression of lettuce in 1996-98. One exception was that RGR was affected by solution temperature in Winter and Spring 1998, when it warmed from 15 to $2{ }^{\circ} \mathrm{C}$. As shown at that time, this effect could be better explained by the effect of irradiance on RGR as sunlight increased from 2.4 to $8 \mathrm{~mol} \cdot \mathrm{m}^{-2} \cdot \mathrm{d}^{-1}$ in Spring 1998 (Gent, 2003).

\section{Summary}

The experiments on lettuce in 2006-08 were similar to those on spinach in 2009-10, in that the same variables were highly correlated with RGR. However, in comparison with spinach, lettuce had a greater contribution of irradiance, and lesser contributions from temperature and solution nitrate to RGR, implying that lettuce was affected more by irradiance and spinach was affected more by temperature and solution nitrate concentration. The experiments on lettuce in 1996-98 could not be explained by the same variables. The RGR was best explained by solution temperature, with a contribution similar to that for lettuce in 2006-08.

\section{Literature Cited}

Spinach 2009-10. There are fewer studies of the effect of environment on RGR of spinach. The effect of temperature in spinach was about twice that in lettuce, with regression coefficients of 0.0131 and 0.0058 , respectively. This may be due to the effect of temperature on metabolism of sugars in spinach. Sugars in petioles tended to decrease with temperatures up to $20^{\circ} \mathrm{C}$ (Gent, 2016). We saw no effect on RGR of EC, which only varied between 1.0 and $1.4 \mathrm{dS} \cdot \mathrm{m}^{-1}$ in the
Bierhuizen, J.F., J.L. Ebbens, and N.C.A. Koomen. 1973. Effects of temperature and radiation on lettuce growing. Neth. J. Agr. Sci. 21:110-116.

Broadley, M.R., I. Seginer, A. Burns, A.J. EscobarGutierrez, I.G. Burns, and P.J. White. 2003. The nitrogen and nitrate economy of butterhead lettuce (Lactuca sativa var. capitata L.). J. Expt. Bot. 54:2081-2090.

Burns, I.G. 1992. Influence of plant nutrient concentration on growth rate-Use of a nutrient 
interruption technique to determine critical concentrations of $\mathrm{N}, \mathrm{P}$ and $\mathrm{K}$ in young plants. Plant Soil 142:221-233.

Burns, I.G. 1994. A mechanistic theory for the relationship between growth rate and concentration of nitrate $\mathrm{N}$ and organic $\mathrm{N}$ of young plants derived from nutrient interruption experiments. Ann. Bot. 74:159-172.

Buysse, J., H. Van den Broeck, and R. Merckx. 1996. Growth and growth substrate levels in spinach under non-steady state conditions of nitrogen nutrition and light. Physiol. Plant. 98:838-844.

Choi, E.G., B.O. Jin, C.H. Kim, G.Y. Back, B.E. Moon, S.Y. Lee, and H.T. Kim. 2014. Estimate of the LAI to calculate the $\mathrm{CO}_{2}$ consumption of lettuce leaf. Acta Hort. 1037:801-806.

De Pinheiro Henricques, A.R. and L.F.M. Marcelis. 2000. Regulation of growth at steady state nitrogen nutrition in lettuce (Lactuca sativa $\mathrm{L}$.) Interactive effects of nitrogen and irradiance. Ann. Bot. 86:1073-1080.

Demsar, J., J. Osvald, and D. Vodnik. 2004. The effect of light-dependent application of nitrate on the growth of aeroponic grown lettuce (Lactuca sativa L.). J. Amer. Soc. Hort. Sci. 129:570-575.

Eguchi, H., S. Yoshida, K. Toh, M. Hamakoga, and M. Kitano. 1997. Growth of lettuce plants (Lactuca sativa L.) under variable value control of air temperature by using natural light intensity as feedback signal. Biotronics 26:13-20.

Fukuda, N., M. Miyagi, Y. Suzuki, H. Ikeda, and K. Takayanagi. 1999. Effects of supplemental night lighting and $\mathrm{NO}_{3}$ exclusion on the growth and $\mathrm{NO}_{3}$ concentration of leaf sap of greenhouse grown spinach under NFT. J. Jpn. Soc. Hort. Sci. 68:146-151.

Gent, M.P.N. 2002. Growth and composition of salad greens as affected by organic compared to nitrate fertilizer and by environment in high tunnels. J. Plant Nutr. 25:981-998.
Gent, M.P.N. 2003. Effect of conductivity and nitrate supply ratio on nitrate accumulation in hydroponic lettuce. HortScience 38:222-227.

Gent, M.P.N. 2012. Rate of change of composition of lettuce in response to nitrogen depletion or resupply. J. Sci. Food Agr. 92:3007-3015.

Gent, M.P.N. 2014. Effect of daily light integral on composition of hydroponic lettuce. HortScience 49:173-179.

Gent, M.P.N. 2016. Effect of irradiance and temperature on composition of spinach. HortScience 51:133-140.

Hicklenton, P.R. and M.S. Wolynetz. 1987. Influence of light and dark period air temperatures and root temperatures on growth of lettuce in nutrient flow systems. J. Amer. Soc. Hort. Sci. 112:932-935.

Huett, D.O. and E. White. 1992. Determination of critical nitrogen concentrations of lettuce ( $\mathrm{Lac}$ tuca sativa L.) grown in sand culture. Austral. J. Expt. Agr. 32:759-764.

Knight, S.L. and C.A. Mitchell. 1983. Stimulation of lettuce productivity by manipulation of diurnal temperature and light. HortScience 18:462-463.

Miller, W.B. and R.W. Langhans. 1985. Growth and productivity of 'Grand Rapids' lettuce in diurnally fluctuating temperatures and day/ night average temperatures. J. Amer. Soc. Hort Sci. 110:560-565.

Park, M.H. and L. Yong Beom. 2001. Effects of $\mathrm{CO}_{2}$ concentration, light intensity, and nutrient level on growth of leaf lettuce in a plant factory. Acta Hort. 548:377-383.

Qin, L., J. He, and S.K. Lee. 2002. Response of lettuce (Lactuca sativa L.) growth to reciprocal root-zone temperature (RZT) transfer at different growth stages. J. Hort. Sci. 77:683-690.

Rivera, C.M., G. Colla, Y. Rouphael, M. Cardarellli, F. Saccardo, A. Battistelli, S. Moscatello, and S. Proietti. 2009. Influence of nutrient solution composition on yield and quality of spinach grown in floating systems. Acta Hort. 807:527531.

Roosta, H.R. 2011. Interaction between water alkalinity and nutrient solution $\mathrm{pH}$ on the vegetative growth, chlorophyll fluorescence, and leaf $\mathrm{Mg}, \mathrm{Fe}, \mathrm{Mn}$, and $\mathrm{Zn}$ concentrations in lettuce. J. Plant Nutr. 34:717-731.

Salomez, J. and G. Hofman. 2007. A soil temperature short wave radiation growth model for Butterhead lettuce under protected cultivation in Flanders. J. Plant Nutr. 30:397-410.

Scaife, M.A. 1973. The early relative growth rates of six lettuce cultivars as affected by temperature. Ann. Appl. Biol. 74:119-128.

Scuderi, D., F. Giuffrida, and G. Noto. 2009. Effects of nutrient solution EC on yield, quality, and shelf life of lettuce grown in floating system. Acta Hort. 807:221-226.

Smolders, E. and R. Merckx. 1992. Growth and root shoot ratio of spinach plants as affected by nitrogen supply. Plant Cell Environ. 15:795807.

Steingrobe, B. and M.K. Schenk. 1994. A model relating the maximum nitrate inflow of lettuce (Lactuca sativa L.) to the growth of roots and shoots. Plant Soil 162:249-257.

Ter Steege, M.W., I. Stulen, P.K. Wiersema, A.J.M. Paans, W. Vaalburg, P.J.C. Kuiper, and D.T. Clarkson. 1998. Growth requirement for $\mathrm{N}$ as a criterion to assess the effects of physical manipulation on nitrate uptake fluxes in spinach. Physiol. Plant. 103:181-192.

Thompson, H.C., R.W. Langhans, A.J. Both, and L.D. Albright. 1998. Shoot and root temperature effects on lettuce growth in a floating hydroponic system. J. Amer. Soc. Hort. Sci. 123:361-364.

Van der Boon, J., J.W. Steenhuizen, and E.G. Steingrover. 1990. Growth and nitrate concentration of lettuce as affected by total nitrogen and chloride concentration, $\mathrm{NH}_{4} / \mathrm{NO}_{3}$ ratio and temperature of the recirculating nutrient solution. J. Hort. Sci. 65:309-321. 